\title{
Identifikasi Kandungan Kolesterol pada Udang Kelong Basah Menggunakan Metode Gas Chromatography-Mass Spectroscopy (GC-MS)
}

\author{
M. Yasser \\ ${ }^{1}$ Jurusan Teknik Kimia Politeknik Negeri Ujung Pandang, Jl. Perintis Kemerdekaan KM. 10 Tamalanrea Makassar \\ a myasser1988@gmail.com
}

\begin{abstract}
This study aims to identify the content of cholesterol in Kelong shrimp that have been preserved with ice cubes. The identification of cholesterol is done using Gas Chromatography-Mass Spectroscopy (GC-MS). The result of Chromatograms from analysis using GC-MS that has been compared to a standard cholesterol showed that shrimp Kelong which have been preserved ice cubes contain cholesterol.
\end{abstract}

Keywords-Shrimp Kelong; Gas Chromatography-Mass Spectroscopy (GC-MS); Cholesterol

\begin{abstract}
Abstrak - Penelitian ini bertujuan untuk mengidentifikasi kandungan kolesterol pada Udang Kelong yang telah diawetkan dengan es batu. Identifikasi kolesterol dilakukan dengan menggunakan Gas Chromatography-Mass Spectroscopy (GC-MS). Kromatogram yang dihasilkan dari hasil analisis menggunakan GC-MS yang telah dibandingkan dengan standar kolesterol menunjukkan bahwa Udang Kelong yang telah di awetkan dengan es batu mengandung Kolesterol.
\end{abstract}

Kata Kunci-Udang Kelong; Kromatografi Gas-Spektroskopi Massa (GC-MS); Kolesterol

\section{Pendahuluan}

Kolesterol merupakan jenis steroid yang paling dikenal dengan 27 atom karbon. Kolesterol hanya ditemukan pada pangan yang berasal dari hewan. Kolesterol pun dapat membentuk produk hasil oksidasi kolesterol dalam pangan olahan selama proses pemanasan, contohnya pada pengolahan pasta yang mengandung telur. Kecukupan asupan kolesterol yang dibutuhkan oleh tubuh dapat diperoleh dari bahan pangan yang dikonsumsi sehari-hari [1].

Menurut data dari Kementerian Kesehatan penyakit jantung di Indonesia meningkat dari tahun ke tahun. Beberapa faktor diduga sebagai pemicu penyakit jantung diantaranya obesitas, karena meningkatnya IMT yang menyebabkan meningkatnya fungsi metabolik tubuh yang membutuhkan suplai oksigen lebih besar, sehingga beban kerja otot jantung meningkat. Kolesterol tinggi juga menjadi faktor pemicu penyakit jantung koroner karena kolesterol tinggi penyebab terjadinya sumbatan di pembuluh arah perifer yang mengurangi suplai darah ke jantung. Kolesterol tinggi juga dapat menjadi pemicu hipertensi dan stroke [2].

Udang merupakan salah satu hasil perikanan yang memiliki prospek ekonomis yang tinggi karena digemari banyak orang. Di dalam udang terdapat vitamin A, vitamin B 1, zat kapur maupun fosfor [3], Darmono dalam Maharani et al [4]., menambahkan bahwa udang merupakan salah satu bahan makanan sumber protein hewani bermutu tinggi yang sangat digemari oleh konsumen dalam negeri maupun luar negeri karena memiliki rasa yang sangat gurih dan kadar kolesterolnya yang lebih rendah dari pada hewan mamalia.

Udang Kelong dengan nama lain udang putih merupakan salah satu jenis udang yang banyak terdapat di perairann Indonesia bahkan dengan mudah dapat diperoleh di pasar tradisional. Pengawetan pada udang adalah salah satu cara untuk menjaga kualitas dari udang. Teknik pengawetan dengan pendinginan mencegah pertumbuhan mikroba termofilik dengan sebagian besar mikroba mesofilik. Sejumlah mikroba psikrofilik mengakibatkan kebusukan bahan dan produk pangan, tetapi miroba psikrofilik tidak ada yang bersifat patogen. Pendinginan $5-7^{\circ} \mathrm{C}$ mengakibatkan penundaan kebusukan oleh mikroba dan mencegah pertumbuhan mikroba patogen. Pembekuan merupakan proses pengolahan, yaitu suhu produk atau bahan pangan diturunkan di bawah titik beku, dan sejumlah air berubah bentuk menjadi kristal es [5]. 
Identifikasi kolesterol dari berbagai bahan pangan yang dikonsumsi setiap harinya sangat penting untuk diketahui mengingat setiap jenis bahan pangan berpotensi mengandung kolesterol. Berdasarkan penelitian Osman dan Chin [6], kolesterol dapat dideteksi dan ditentukan kuantitasnya dengan menggunakan beberapa metode seperti spektrofotometer UV-VIS, kromatografi gas (GC), dan kromatografi cair kinerja tinggi (HPLC) dengan detektor UV. Dengan metode spektrofotometer UV-VIS kolesterol dapat dideteksi hingga konsentrasi $14 \mu \mathrm{g} / \mathrm{mL}$, dengan menggunakan GC kolesterol terdeteksi hingga 4,00 $\mu \mathrm{g} / \mathrm{mL}$, dan dengan menggunakan HPLC-UV terdeteksi hingga $0,08 \mu \mathrm{g} / \mathrm{mL}$.

\section{Metode Penelitian}

\section{A. Pengawetan Sampel Udang}

Sampel udang di awetkan dengan menggunakan es batu pada suhu $5-7{ }^{\circ} \mathrm{C}$

\section{B. Pengukuran dengan GC-MS}

a) Sampel udang ditimbang dalam erlenmeyer sebanyak 1 gram.

b) Kemudian ditambahkan $2 \mathrm{ml} \quad \mathrm{KOH} \quad 50 \%$ homogenkan. Lalu tambahkan Etanol $95 \%$

c) Selanjutnya disaponifikasi pada suhu $80-100^{\circ} \mathrm{C}$ selama 15 menit,

d) Kemudian sampel didinginkan dengan air, kemudian ditambahkan $10 \mathrm{ml}$ Toluene lalu kocok 10 detik.

e) Masukkan dalam corong pemisah tambahkan $10 \mathrm{ml}$ $\mathrm{KOH} 1 \mathrm{M}$

f) Tambahkan etanol $1 \mathrm{ml} 95 \%$

g) Pisahkan, buang lapisan dibawah. Lalu tambahkan aquadest $10 \mathrm{ml}$ lalu buang sisahkan lapisan di atas lakukan dua kali.

h) Masukkan campuran ekstrak pada tabung vakum

i) Kemudian 1 mikroliter diinjeksikan ke dalam gas kromatorafi.

j) Recorder menghasilkan data berupa kurva setelah beberapa menit.

k) Data yang dihasilkan dibandingkan dengan standar kolestrol

\section{Hasil dan Pembahasan}

Sampel berupa udang kelong sebelum dilakukan analisis menggunakan GC-MS dilakukan perlakuan saponifikasi dengan penambahan etanol dan larutan $\mathrm{KOH}$ dalam air yang bertujuan untuk mengekstraksi lemak. Saponifikasi yang menggunakan etanol dan larutan $\mathrm{KOH}$ dalam air lebih efektif menghilangkan semua pengotor (asam lemak) dalam bentuk busa dapat dipisahkan selama ekstraksi dan purifikasi. Sehingga dapat mengeliminasi gangguang asam lemak untuk mengekstrak kolesterol.

Udang kelong yang telah disaponifikasi, diekstraksi dan purifikasi selanjutnya dilakukan pengukuran dengan menggunakan GC-MS. Secara sederhana prinsip kromatografi gas adalah udara dilewatkan melalui nyala hydrogen (hydrogen flame) selanjutnya uap organik tersebut akan terionisasi dan menginduksi terjadinya aliran listrik pada detektor, kuantitas aliran listrik sebanding dengan ion. Kromatogram (Gambar 1) menunjukkan bahwa terdapat 30 senyawa yang teridentifikasi terkandung dalam Udang kelong Basah yang salah satunya yaitu Kolesterol pada Retention Time 33.108. Retention Time menunjukkan waktu yang diperlukan suatu senyawa untuk terbaca pada suatu kromatografi. Dari hasil pengukuran (Tabel 1) diperoleh data berupa Retention Time untuk sampel udang kelong sebesar 33.108 (Gambar 1) dan Retention Time untuk kolesterol standar (Gambar 2) sebesar 33.012. Dari data tersebut diperoleh bahwa antara Udang kelong dan kolesterol standar memiliki Retention Time yang hampir sama menunjukkan bahwa Udang kelong memiliki kandungan Kolesterol.

Tabel 1. Hasil pengukuran menggunakan GC-MS

\begin{tabular}{|c|c|}
\hline Sampel & Ret. Time (min) \\
\hline Udang Kelong & 33.108 \\
\hline Kolesterol Standar & 33.012 \\
\hline
\end{tabular}


DATA REPORT GCMS-QP2010 ULTRA SHIMADZU
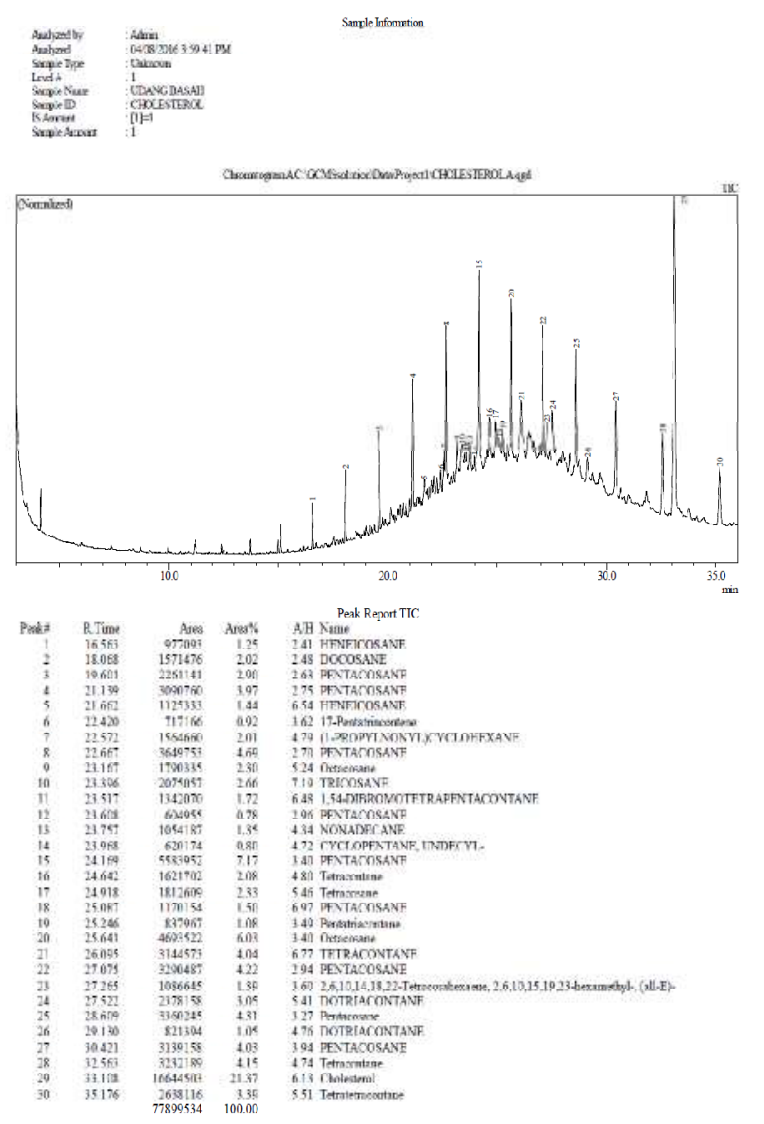

Gambar 1. Kromatogram hasil analisis udang kelong dengan GC-MS

DATA REPORT CCMS QP2O 10 ULTRA SHIMADZU
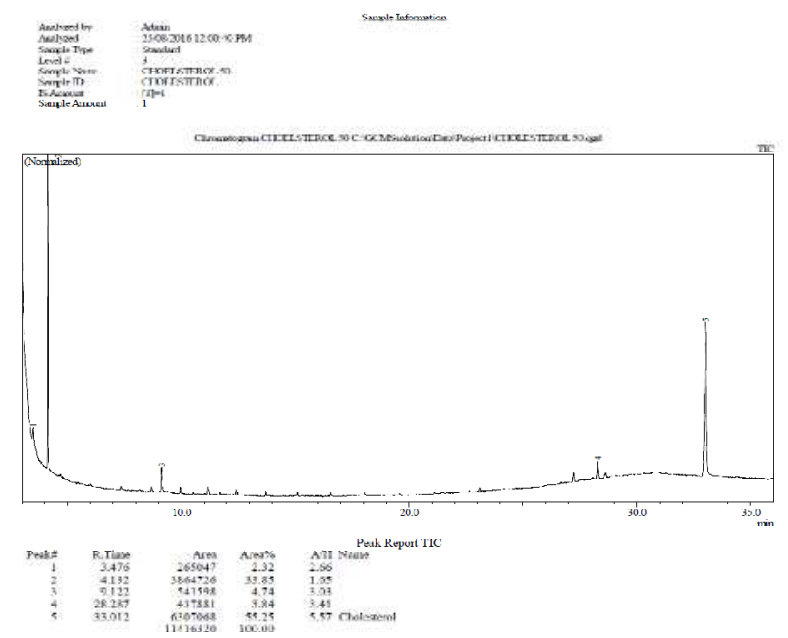

Selain itu, hasil perbandingan peak kromatogram Udang kelong (Peak 29) dengan library kolesterol pada GC-MS (Gambar 3) menunjukkan bahwa kromatogram yang dihasilkan oleh udang kelong identik dengan kolesterol memperkuat dugaan bahwa udang kelong memiliki kandungan kolesterol.

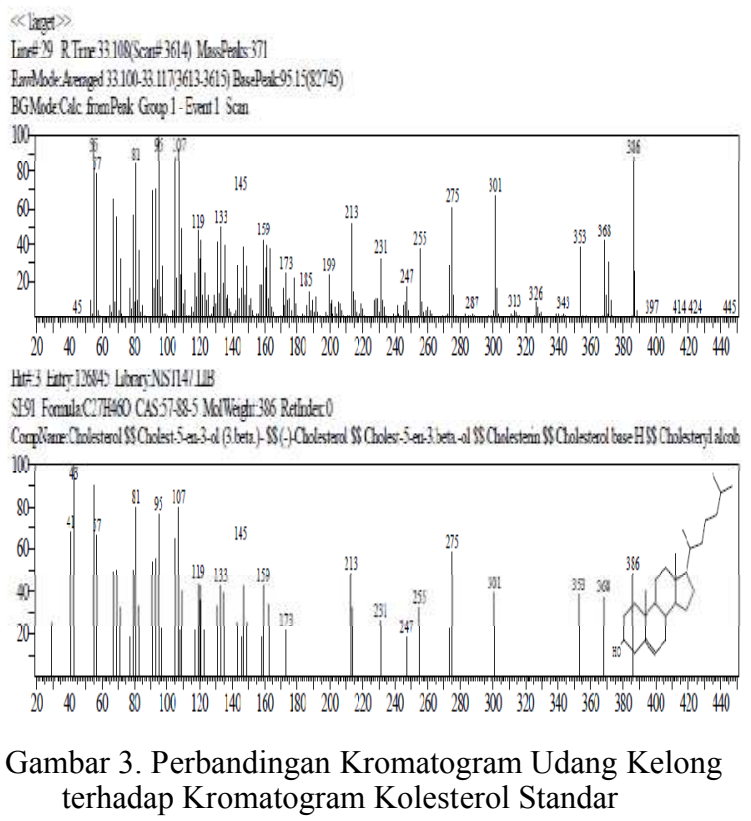

\section{Kesimpulan}

1. Berdasarkan penelitian yang telah dilakukan maka dapat disimpulkan bahwa Udang kelong yang telah diawetkan dengan es batu mengandung kolesterol.

2. Penelitian selanjutnya diharapkan mampu untuk menghitung konsentrasi yang terdapat pada Udang Kelong.

\section{Ucapan Terima Kasih}

Ucapan terima kasih terkhusus saya berikan kepada Nanayanti dan Akhmad Rifai, S.Si yang telah meluangkan waktu dan tenaganya dalam penyelesaian penelitian ini.

Gambar 2. Kromatogram hasil analisis kolesterol standar dengan GC-MS 


\section{Daftar Pustaka}

[1] Lioe, H.N., Setaningrum, t., dan Anggraini, R. " Validasi Metode Analisis Kolesterol dalam Telur dengan HPLC-ELSD" JIPI, Vol. 18 (3): 178-185, Desember 2013. ISSN 0853 - 4217

[2] Soleha, Maratu. "Kadar Kolesterol Tinggi Dan Faktor-Faktor Yang Berpengaruh Terhadap Kadar Kolesterol Darah", Jurnal Biotek Medisiana Indonesia. Vol.1.2.2012: 85-92
[3] Sulistiyono, E., Sutarno dan Moria S.B. "Variasi Genetik Populasi Udang Putih (Penaeus merguiensis de Man) di Juwana dan Banyuwangi Berdasarkan Data Elektroforesis Enzim". Bioteknologi 2 (1): 1-8, Mei 2005, ISSN: 0216-6887.

[4] Maharani, G., Sunarti., Triastuti., J.Juniastuti dan Tutik. “ Kerusakan dan Jumlah Hemosit Udang Windu (Penaeus monodon Fab.) yang Mengalami Zoothamniosis”. Jurnal Ilmiah Perikanan dan Kelautan Vol. 1 No. 1, April 2009.

[5] Estiasih, Teti., Ahmadi. Teknologi Pengolahan Pangan. Jakarta : PT Bumi Aksara. 2011.

[6] Osman, H., and Chin, Y.K. Comparative sensitivities of cholesterol analysis using GC, HPLC and spectrophotometric methods. The Malay J Anal Sci. 10(2): 205-210. 2006. 